\title{
Diastereoselective synthesis of 3,4-dihydro-2H-pyran-4- carboxamides through an unusual regiospecific quasi-hydrolysis of a cyano group
}

\author{
Mikhail Yu. levlev ${ }^{* 1}$, Oleg V. Ershov ${ }^{1}$, Mikhail Yu. Belikov¹, Angelina G. Milovidova1, \\ Viktor A. Tafeenko ${ }^{2}$ and Oleg E. Nasakin ${ }^{1}$
}

\author{
Full Research Paper

\section{Address:} \\ ${ }^{1}$ Department of Organic and Pharmaceutical Chemistry, Ulyanov \\ Chuvash State University, Moskovskiy av. 15, Cheboksary, Russia \\ and ${ }^{2}$ Department of General Chemistry, Lomonosov Moscow State \\ University, Leninskie gory 1, Moscow, Russia \\ Email: \\ Mikhail Yu. levlev* - hiliam@bk.ru \\ * Corresponding author \\ Keywords: \\ diastereoselectivity; 3,4-dihydro-2H-pyran-4-carboxamide; nitriles; \\ pyran; quasi-hydrolysis
}

\author{
Beilstein J. Org. Chem. 2016, 12, 2093-2098. \\ doi:10.3762/bjoc. 12.198 \\ Received: 18 June 2016 \\ Accepted: 15 September 2016 \\ Published: 27 September 2016 \\ Associate Editor: T. J. J. Müller \\ (c) 2016 levlev et al.; licensee Beilstein-Institut. \\ License and terms: see end of document.
}

\begin{abstract}
An efficient diastereoselective approach for the synthesis of functionalized 3,4-dihydro-2 $\mathrm{H}$-pyran-4-carboxamides with variable frame was developed based on the reaction of available 4-oxoalkane-1,1,2,2-tetracarbonitriles (adducts of TCNE and ketones) with aldehydes in an acidic media. An unusual process of quasi hydrolysis of the cyano group was observed in the course of the described regio- and diastereoselective transformation.
\end{abstract}

\section{Introduction}

Dihydro- and tetrahydropyran moieties are very important structural fragments in organic synthesis. They are part of many natural compounds, biologically active substances and drugs [1-4]. For instance, Zanamivir and Laninamivir which are recommended for the treatment and prophylaxis of influenza caused by influenza A and B viruses contain a 3,4-dihydro- $2 \mathrm{H}$ pyran fragment [5]. Moreover, dihydropyrans have been proven to be particularly useful in the preparation of cyclic components of macrocyclic antibiotics [6,7] and as precursors in the synthesis of C-glycosides [8].
Modern and convenient methods for the construction of 3,4dihydro- $2 \mathrm{H}$-pyrans are based on the interaction between ylidene derivatives of methylene-active compounds and $\beta$-oxo derivatives of acids or ketones [9-11], and also on the reactions of phenols with carbonyl compounds [12]. An interesting example that had been recently described is the involvement of diazolactones in an inverse electron-demand Diels-Alder reaction [13]. At the same time the synthesis of 3,4-dihydro- $2 \mathrm{H}$-pyrans with a carboxamide group is a not sufficiently explored area. There is only one way to produce 3,4 -dihydro- $2 H$-pyran-4-carbox- 
amides from substrates containing no pyran ring described in the literature (Scheme 1) [14].

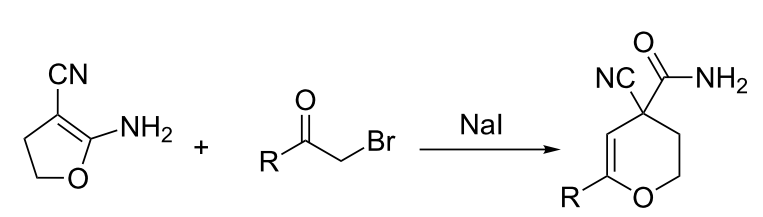

Scheme 1: An exclusive approach to 3,4-dihydro-2H-pyran-4-carboxamides from non-pyran sources.

In view of a directed synthesis of inaccessible heterocyclic molecules, 4-oxoalkane-1,1,2,2-tetracarbonitriles $\mathbf{1}$ are very promising substrates. They can be easily prepared from an appropriate ketone and TCNE (Scheme 2). Previously we reported about several ways of heterocyclization thereof [15-23], including the formation of pyran derivatives [20-24].

Our recent work should be noted individually, we were able to prepare various functionalized pyrano[3,4-c]pyrrole derivatives via diastereoselective cascade reaction [23]. The crucial stage of the described transformation is the formation of a pyran-4carboxamide intermediate. A trace amount of it was isolated accidentally and we could not repeat this procedure and characterize the compound by spectra.

\section{Results and Discussion}

In continuation of our interest in this area, we focused our attention on the extention of the existing methods for the synthesis of a series of pyran heterocycles. Therefore, we have studied more thoroughly the transformation of ketonitriles $\mathbf{1}$ in acidic media in the presences of aldehydes. We had found that 3,3,4tricyano-3,4-dihydro- $2 \mathrm{H}$-pyran-4-carboxamides 2 nevertheless could be obtained in good yields (57-69\%) by the action of hydrochloric acid. A prominent feature of the reaction that has been developed is the possibility to vary substituents at the 2-, 5- and 6-positions of the pyran cycle, using alkyl and aryl moieties to design the rare pyran-4-carboxamide molecules. Moreover, during the regio- and diastereoselective transformation a quasi-hydrolysis of only one of the cyano groups had occurred. As a result only one diastereomer of 3,4-dihydro- $2 H$ pyran-4-carboxamides 2 was obtained (Table 1).

The structure of pyrans 2 as well as the trans configuration of the substituents at the asymmetric atoms $\mathrm{C} 2$ and $\mathrm{C} 4$ were established by X-ray diffraction (Figure 1) [25]. The conformation of the six-membered heterocyclic ring is stabilized by an intermolecular hydrogen bond $\mathrm{C} 2-\mathrm{H} 2 \cdots \mathrm{O} 2$. The distance $\mathrm{O} 2 \cdots \mathrm{H} 2$ is $2.31 \AA$. In the crystal, the molecules form centrosymmetric dimers through hydrogen bonding $\mathrm{N} 1-\mathrm{H} 11 \cdots \mathrm{O} 2(\mathrm{H} 1 \cdots \mathrm{O} 2$ $1.98 \AA$, angle $\mathrm{N} 1-\mathrm{H} 1 \cdots \mathrm{O} 2176^{\circ}$ ). Structures of compounds 2 are also consistent with IR, ${ }^{1} \mathrm{H}$ NMR spectroscopy and mass spectrometry. The IR spectra characterized with the absorption bands of non-conjugated $\mathrm{C} \equiv \mathrm{N}$ in the area of $2240-2260 \mathrm{~cm}^{-1}$ and two intensive bands of amide $\mathrm{N}-\mathrm{H}$ bonds in the area of $3150-3450 \mathrm{~cm}^{-1}$. The ${ }^{1} \mathrm{H}$ NMR spectra of compounds 2 are characterized with two individual downfield signals of amide protons in the area of 8-9 ppm, signals of the OCH fragment in the area of 4.9-6.5 ppm, depending on the substituent $\mathrm{R}^{3}$, and the signals of other appropriate alkyl and aryl substituents.

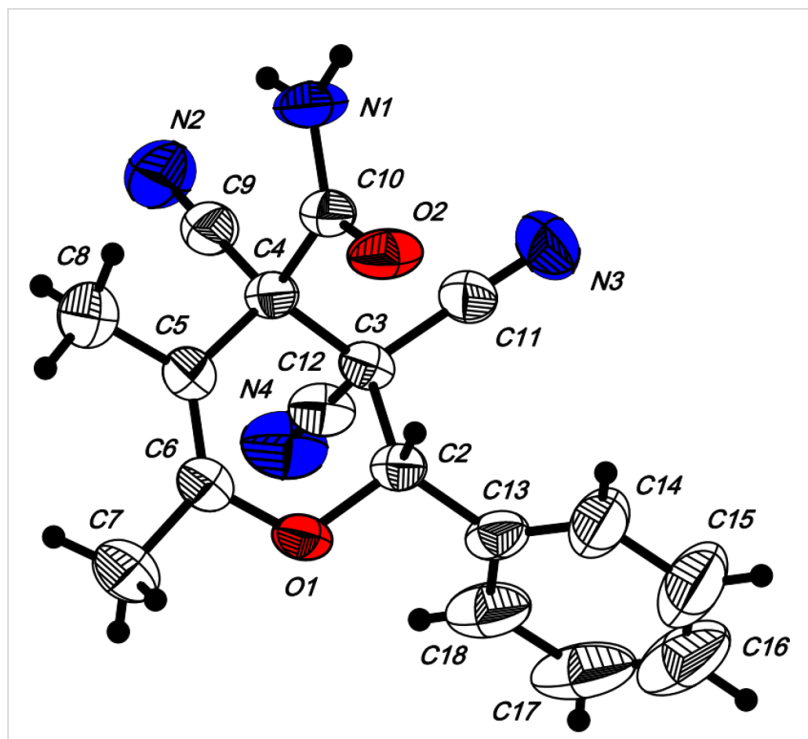

Figure 1: The molecular structure of $2 \mathbf{a}$ with atom-numbering scheme. Displacement ellipsoids are drawn at the $50 \%$ probability level and $\mathrm{H}$ atoms are drawn as small spheres of arbitrary radii. 
Table 1: Synthesis of 3,3,4-tricyano-3,4-dihydro-2H-pyran-4-carboxamides 2.

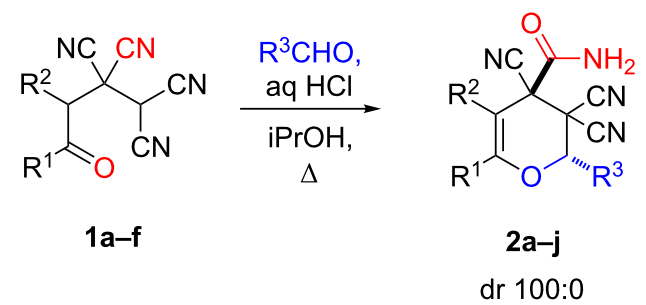

\begin{tabular}{lll}
\hline Entry $\quad$ Ketonitrile & Aldehyde & Product \\
\hline
\end{tabular}

1<smiles>CC(=O)C(C)C(C)(C#N)C(C#N)C(N)C#N</smiles><smiles>COc1ccc(C(C(C)=O)C(C)(C)C([NH3+])C([NH3+])[NH3+])cc1</smiles>

1b<smiles>CC(C(=O)c1ccccc1)C(C)(N)C(C)(N)C(C#N)C#N</smiles>

$1 c$<smiles>CC(C(=O)c1ccc(Cl)cc1)C(C#N)(C#N)C(C#N)C#N</smiles>

1d

5<smiles>CC(N)(C(N)C#N)C(C=[18O])C1CCCCC1=O</smiles>

6<smiles>CC(C#N)(C(N)C#N)C1CCCCC1=O</smiles><smiles>O=Cc1ccccc1</smiles><smiles>CC1=C(C)C(C#N)(C(N)=O)[C@@H](c2ccccc2)O[C@@H]1C</smiles>

2a<smiles>COc1ccc(C2=C(C)O[C@@H](c3ccccc3)C(C#N)(C#N)C2(C#N)C(N)=O)cc1</smiles>

2b<smiles>CC(C)C=O</smiles><smiles>CC(C)C=O</smiles><smiles>CC=O</smiles><smiles>CC(C)CC=O</smiles><smiles>CC1=C(c2ccccc2)O[C@@H](C(C)C)C(C#N)(C(N)=O)C1(C#N)C#N</smiles>

2c<smiles>CC1=C(c2ccc(Cl)cc2)O[C@@H](C(C)C)C(C#N)(C(N)=O)C1(C#N)C#N</smiles>

2d<smiles>C[C@H]1OC2=C(CCCC2)C(C#N)(C(N)=O)C1(C#N)C#N</smiles><smiles>CC(C)C[C@H]1OC2=C(CCCC2)C(C#N)(C(N)=O)C1(C)C#N</smiles>

$2 f$
57

59 
Table 1: Synthesis of 3,3,4-tricyano-3,4-dihydro-2H-pyran-4-carboxamides 2. (continued)

7<smiles>CC(N)(C1CCCCC1=O)C(C=O)C(N)N</smiles>

8<smiles>CC(N)(C(N)C#N)C(C(N)C#N)C1CCCCC1=O</smiles>

9<smiles>CC(N)(C(N)C#N)C(C)(N)C1CCCCC1=O</smiles>

10

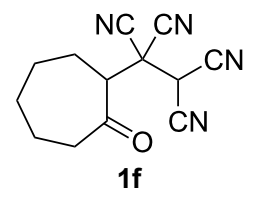<smiles>O=CC1CCCCC1</smiles><smiles>O=Cc1ccccc1</smiles><smiles>O=Cc1ccccc1Br</smiles><smiles>O=Cc1ccccc1</smiles><smiles>N#CC1(C(N)=O)C2=C(CCCC2)O[C@H](C2CCCCC2)C1(C#N)C#N</smiles>

$2 g$<smiles>N#CC1(C(N)=O)C2=C(CCCC2)O[C@H](c2ccccc2)C1(C#N)C#N</smiles>

2h<smiles>N#CC1(C(N)=O)C2=C(CCCC2)O[C@H](c2ccccc2Br)C1(C#N)C#N</smiles>

2i<smiles>N#CC1(C(N)=O)C2=C(CCCCC2)O[C@H](c2ccccc2)C1(C#N)C#N</smiles>

2j
There are two cascade mechanisms that could be proposed for the 3,4-dihydro-2H-pyran-4-carboxamides 2 formation (Scheme 3).
Both mechanisms apparently start from the interaction of ketonitrile 1 with aldehyde under subsequent formation of the intermediate 2,7-dioxabicyclo[3.2.1] octane derivative 3. This

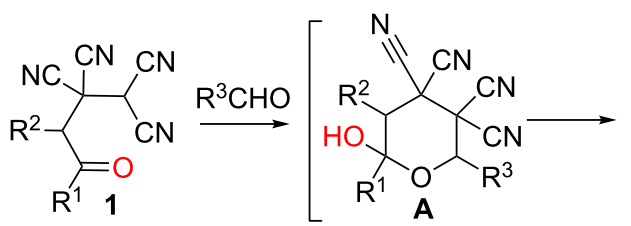<smiles>[R]C1OC2([R])OC(=N)C(C)(C1(C#N)C#N)C2(C#N)C#N</smiles><smiles>[R]C1OC2([R])OC([R])C([R])(NC)C(C#N)(C1(C#N)C#N)C2([R])O</smiles><smiles>[R]C1OC([R])(O)C([R])C(C#N)(C(N)=O)C1(C#N)C(N)=O</smiles>

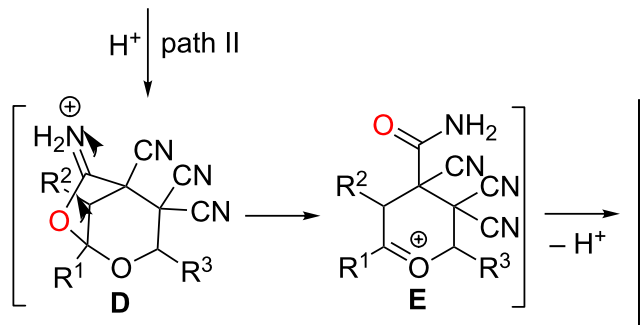

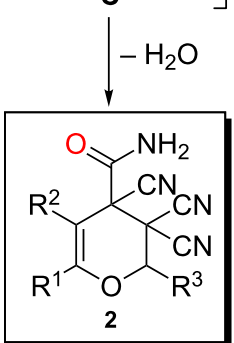


reaction was separately described by us previously and it is the crucial reason for the diastereoselectivity of the whole transformation $[21,22]$. Further acid-catalyzed addition of water to the imino group (B) is probably accompanied with decyclization (C) and dehydratation processes forming compound $\mathbf{2}$ (Scheme 3, path I). However, according to the literature, in most cases, the addition of water to the similar cyclic iminoethers leads to hydrolysis and formation of lactones $[26,27]$. Another probable pathway involves the protonation of the imino group nitrogen atom to form an iminium salt (D) and subsequent decyclization of iminolactone ring (E) without participation of water (Scheme 3, path II).

To establish the actual mechanism and to prove the intermediate formation of bicyclo[3.2.1] octane derivatives 3 we carried out the reaction of specially prepared 6-imino-2,7-dioxabicyclo[3.2.1] octane-3,3,4-tricarbonitrile $\mathbf{3 h}$ [21] with dry trifluoroacetic acid under anhydrous conditions (Table 2, entry 6). The successful implementation of this process and isolation of product $\mathbf{2 h}$ with good yield indicate the path of transformations without the participation of water (Scheme 3, path II) as actual.

Such an abnormal resistance of the imine moiety to be simply hydrolyzed in aqueous acidic media is very exciting. Therefore we attempted to use other acids to investigate the behavior of the imine moiety in presence thereof, but all acids promote only the iminolactone decyclization process without traces of lactone derivative 4 (Table 2).

It is also important to note that during the reaction pathway (Scheme 3) a carbonyl-assisted carbonitrile hydration effect (CACHE) was occured. The carbonyl group, through the forma- tion of hemiketal (A), became a source of a hydroxy group that cyclized regiospecifically to the spatially proximate cyano group and caused the carboxamide formation. CACHE processes are essential for the chemistry of oxonitriles and sometimes can be the reason for unusual quasi-hydrolysis of the cyano group under mild conditions $[15,19,23]$, but it was not mentioned by many authors [28-31].

\section{Conclusion}

In conclusion, we have developed a new efficient approach to a rare group of heterocycles, namely, functionalized 3,4-dihydro$2 \mathrm{H}$-pyran-4-carboxamides with variable frame and exceptional diastereoselectivity based on the reaction of available 4-oxoalkane-1,1,2,2-tetracarbonitriles (adducts of TCNE and ketones) with aldehydes in acidic media. Unusual processes of regiospecific quasi-hydrolysis of a cyano group and abnormal resistance of the imine moiety to be hydrolyzed in aqueous acidic media were observed in the course of the described transformation. Moreover, the intermediate 6-imino-2,7-dioxabicyclo[3.2.1] octane-4,4,5-tricarbonitriles 3 had demonstrated a cytotoxic activity in various cancer cell lines [32], therefore the derived 3,4-dihydro-2H-pyrans 2 are very promising for biological studies.

\section{Supporting Information}

\section{Supporting Information File 1}

Experimental data and characterization of all new compounds.

[http://www.beilstein-journals.org/bjoc/content/ supplementary/1860-5397-12-198-S1.pdf]

Table 2: Acid-catalysts screening ${ }^{a}$

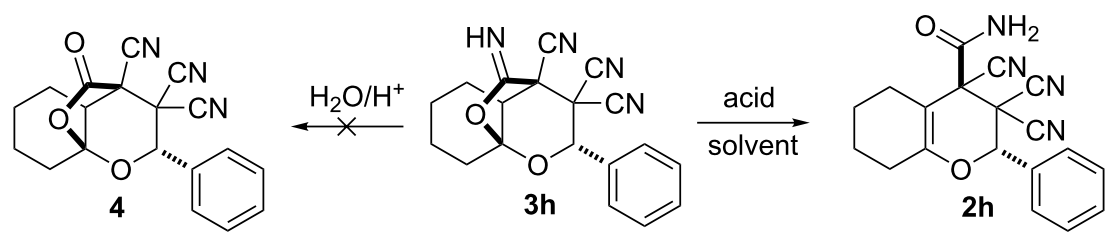

\begin{tabular}{|c|c|c|c|c|c|}
\hline Entry & Acid & Co-solvent & Conditions & Time (min) & Yield after $2 h^{b}(\%)$ \\
\hline 1 & $\mathrm{HCl}(\mathrm{aq} 15 \%)$ & iPrOH & $80^{\circ} \mathrm{C}$ & 5 & 71 \\
\hline 2 & $\mathrm{HBr}(\mathrm{aq} 40 \%)$ & iPrOH & $80^{\circ} \mathrm{C}$ & 3 & 65 \\
\hline 3 & $\mathrm{HNO}_{3}(\mathrm{aq} 50 \%)$ & - & $80^{\circ} \mathrm{C}$ & 3 & 67 \\
\hline 4 & $\mathrm{H}_{2} \mathrm{SO}_{4}(\mathrm{aq} 50 \%)$ & 1,4-dioxane & $\mathrm{rt}$ & 15 & $-^{c}$ \\
\hline 5 & $\mathrm{CH}_{3} \mathrm{COOH}$ (dry) & - & $110^{\circ} \mathrm{C}$ & 5 & $-d$ \\
\hline 6 & $\mathrm{CF}_{3} \mathrm{COOH}$ (dry) & - & $\mathrm{rt}$ & 10 & 69 \\
\hline
\end{tabular}

aReaction conditions: $3 \mathrm{~h}(0.5 \mathrm{mmol})$, acid $(0.75 \mathrm{~mL})$, solvent $\left(0.75 \mathrm{~mL}\right.$, if marked); blsolated yield; ${ }^{\mathrm{c}}$ The reaction does not stop at the amide formation, further transformations proceeds. ${ }^{\mathrm{d}}$ The results were published previously [23]. 


\section{Acknowledgements}

This work was supported by a stipend of the President of the Russian Federation for young scientists and graduate students (SP-127.2016.4). The XRD study was carried out using the equipment purchased from the funds of the program of development of the Moscow University and within the framework of the agreement on collaboration between the Chemical Department of the Lomonosov Moscow State University and the Chemical-Pharmaceutical Department of the I.N. Ulyanov Chuvash State University

\section{References}

1. Marco, J. A.; Carda, M.; Murga, J.; Falomir, E. Tetrahedron 2007, 63, 2929-2958. doi:10.1016/j.tet.2006.12.047

2. Elliott, M. C. J. Chem. Soc., Perkin Trans. 12002 , 2301-2323. doi:10.1039/B201515N

3. Lin, C.-H.; Chang, T.-C.; Das, A.; Fang, M.-Y.; Hung, H.-C.; Hsu, K.-C.; Yang, J.-M.; von Itzstein, M.; Mong, K. K. T.; Hsu, T.-A.; Lin, C.-C. Org. Biomol. Chem. 2013, 11, 3943-3948. doi:10.1039/C3OB40624E

4. Koester, D. C.; Werz, D. B. Beilstein J. Org. Chem. 2012, 8, 675-682. doi:10.3762/bjoc.8.75

5. von Itzstein, M.; Wu, W.-Y.; Kok, G. B.; Pegg, M. S.; Dyason, J. C.; Jin, B.; Phan, T. V.; Smythe, M. L.; White, H. F.; Oliver, S. W.; Colman, P. M.; Varghese, J. N.; Ryan, D. M.; Woods, J. M.; Bethell, R. C.; Hotham, V. J.; Cameron, J. M.; Penn, C. R. Nature 1993, 363, 418-423. doi:10.1038/363418a0

6. Paterson, I.; Cumming, J. G.; Ward, R. A.; Lamboley, S. Tetrahedron 1995, 51, 9393-9412. doi:10.1016/0040-4020(95)00546-K

7. Paterson, I.; Smith, J. D.; Ward, R. A. Tetrahedron 1995, 51, 9413-9436. doi:10.1016/0040-4020(95)00547-L

8. Parker, K. A.; Coburn, C. A.; Koh, Y.-h. J. Org. Chem. 1995, 60, 2938-2941. doi:10.1021/jo00114a057

9. Gajulapalli, V. P. R.; Lokesh, K.; Vishwanath, M.; Kesavan, V. RSC Adv. 2016, 6, 12180-12184. doi:10.1039/C5RA25025K

10. Biswas, S.; Dagar, A.; Mobin, S. M.; Samanta, S. Org. Biomol. Chem. 2016, 14, 1940-1945. doi:10.1039/C5OB02400E

11. Ta, L.; Axelsson, A.; Sundén, H. Green Chem. 2016, 18, 686-690. doi:10.1039/C5GC01965F

12. Shirini, F.; Abedini, M.; Seddighi, M.; Jolodar, O. G.; Safarpoor, M.; Langroodi, N.; Zamani, S. RSC Adv. 2014, 4, 63526-63532. doi:10.1039/C4RA12361A

13. Diac, A. P.; Țepeş, A.-M.; Soran, A.; Grosu, I.; Terec, A.; Roncali, J.; Bogdan, E. Beilstein J. Org. Chem. 2016, 12, 825-834. doi:10.3762/bjoc.12.81

14. Maruoka, H.; Okabe, F.; Yamagata, K. Heterocycles 2007, 74, 383-396. doi:10.3987/COM-07-S(W)16

15. Ershov, O. V.; Fedoseev, S. V.; Belikov, M. Yu.; levlev, M. Yu. RSC Adv. 2015, 5, 34191-34198. doi:10.1039/c5ra01642h

16. Belikov, M. Yu.; Fedoseev, S. V.; levlev, M. Yu.; Ershov, O. V.; Tafeenko, V. A. RSC Adv. 2015, 5, 65316-65320. doi:10.1039/c5ra11304k

17. Belikov, M. Yu.; levlev, M. Yu.; Belikova, I. V.; Ershov, O. V.; Tafeenko, V. A.; Surazhskaya, M. D. Chem. Heterocycl. Compd. 2015, 51, 518-525. doi:10.1007/s10593-015-1731-4

18. Ershov, O. V.; Maksimova, V. N.; Lipin, K. V.; Belikov, M. Yu.; levlev, M. Yu.; Tafeenko, V. A.; Nasakin, O. E. Tetrahedron 2015, 71 7445-7450. doi:10.1016/j.tet.2015.06.031
19. Fedoseev, S. V.; Ershov, O. V.; Belikov, M. Yu.; Lipin, K. V.; Bardasov, I. N.; Nasakin, O. E.; Tafeenko, V. A. Tetrahedron Lett. 2013, 54, 2143-2145. doi:10.1016/j.tetlet.2013.02.043

20. Sheverdov, V. P.; Ershov, O. V.; Nasakin, O. E.; Chernushkin, A. N.; Tafeenko, V. A. Russ. J. Org. Chem. 2002, 38, 1001-1004. doi:10.1023/A:1020801612443

21. Ershov, O. V.; levlev, M. Yu.; Tafeenko, V. A.; Nasakin, O. E. Green Chem. 2015, 17, 4234-4238. doi:10.1039/c5gc00909j

22. levlev, M. Yu.; Ershov, O. V.; Milovidova, A. G.; Belikov, M. Yu.; Nasakin, O. E. Chem. Heterocycl. Compd. 2015, 51, 457-461. doi:10.1007/s10593-015-1720-7

23. levlev, M. Yu.; Ershov, O. V.; Tafeenko, V. A. Org. Lett. 2016, 18, 1940-1943. doi:10.1021/acs.orglett.6b00867

24. Rappoport, Z.; Ladkani, D. J. Chem. Soc., Perkin Trans. 11974 , 2595-2601. doi:10.1039/P19740002595

25. The crystallographic data for this molecule can be obtained free of charge from the Cambridge Crystallographic Data Centre via http://www.ccdc.cam.ac.uk/data_request/cif. The CCDC number is 1469776.

26. Belikov, M. Yu.; Ershov, O. V.; Lipovskaya, I. V.; Fedoseev, S. V.; Lipin, K. V.; Nasakin, O. E. Russ. J. Org. Chem. 2013, 49, 1195-1198. doi:10.1134/S1070428013080162

27. Vasil'ev, A. N.; Lyshchikov, A. N.; Nasakin, O. E.; Kayukov, Ya. S.; Tafeenko, V. A. Russ. J. Org. Chem. 2005, 41, 279-282. doi:10.1007/s11178-005-0157-3

28. Shen, X.-L.; Zhao, R.-R.; Mo, M.-J.; Peng, F.-Z.; Zhang, H.-B.; Shao, Z.-H. J. Org. Chem. 2014, 79, 2473-2480. doi:10.1021/jo402741g

29. Gartshore, C. J.; Lupton, D. W. Angew. Chem., Int. Ed. 2013, 52, 4113-4116. doi:10.1002/anie.201209069

30. Ergün, Y.; Okay, G.; Patir, S. J. Heterocycl. Chem. 2002, 39, 315-317. doi:10.1002/jhet.5570390212

31. Kayukov, Ya. S.; Bardasov, I. N.; Ershov, O. V.; Nasakin, O. E.; Kayukova, O. V.; Tafeenko, V. A. Russ. J. Org. Chem. 2012, 48, 485-490. doi:10.1134/s1070428012040033

32. Nasakin, O. E.; Lyshchikov, A. N.; Kayukov, Ya. S.; Sheverdov, V. P. Pharm. Chem. J. 2000, 34, 170-185. doi:10.1007/BF02524593

\section{License and Terms}

This is an Open Access article under the terms of the Creative Commons Attribution License (http://creativecommons.org/licenses/by/4.0), which permits unrestricted use, distribution, and reproduction in any medium, provided the original work is properly cited.

The license is subject to the Beilstein Journal of Organic Chemistry terms and conditions: (http://www.beilstein-journals.org/bjoc)

The definitive version of this article is the electronic one which can be found at: $\underline{\text { doi: } 10.3762 / \text { bjoc. } 12.198}$ 